Article

\title{
Thoughtfulness and Hospitality: On Refusing Antagonistic Politics at the End of History
}

\author{
John C. McDowell \\ Philosophy, Theology and Moral Theology, St Athanasius College, Donvale VIC3111, Australia; \\ johnmcdowell1977@gmail.com
}

Received: 31 January 2020; Accepted: 24 March 2020; Published: 1 April 2020

check for updates

\begin{abstract}
The paper is constructed around the issues involved for the critical interrogation of the instrumental rationality generating political thoughtlessness in the following claim: "Humanity is in crisis-and there is no exit from that crisis other than solidarity of humans". [Zygmunt Bauman] To even interrogate this as a crisis requires a depth-analysis of the hegemony of subject-formation, and this occurs in two markedly different ways. The first takes shape around a critical investigation of the neoliberalisation of subjectivity through Francis Fukuyama's important text, The End of History and the Last Man. The second subjects the neoliberal post-political global subject to a competing antagonistic political construal in Samuel Huntington's influential The Clash of Civilizations. The implication is of their importance to a genealogy of the range of contemporary political possibilities. The suggested repair takes the form of a particular gesture: a gesture towards subjecting the globally fractured subject takes shape within a theological configuration in terms of a Christic politics of neighbourliness.
\end{abstract}

Keywords: thought and thoughtlessness; Hannah Arendt; the political; neoliberalism; friend/enemy; refugees; disposable persons; Henry Giroux; Francis Fukuyama; Samuel Huntington; critical theory; the neighbour; Immanuel Kant; Nicholas Lash

\section{Preface}

According to Slavoj Žižek, "Contrary to the notion that curiosity is innate to humans—that there is deep within us a Wissenstrieb, a drive to know-Jacques Lacan claims that the spontaneous attitude of a human being is that of 'I don't want to know about it' - a fundamental resistance against knowing too much". ${ }^{1}$ The drive to distraction is a form of thoughtlessness that fails to contend with disciplinary conditions, and thereby perpetuates, by default, the hegemonic conditions. Accordingly, Hannah Arendt argues that a form of thoughtlessness underlies the appearance of totalitarianism. By the notion of 'thoughtlessness', she envisages an inability to think that is not merely the expression of an individual personality but is so of the entire culture that sustains that person, what Theodor Adorno calls "the total structure of our society". ${ }^{2}$ For instance, many a defence of 'democratic' capitalism takes the form of announcing a lack of alternatives. Yet Henry Giroux, for instance, maintains that it is a matter of "political exhaustion and impoverished intellectual visions" when the polis is "fed by the widely popular assumption that there are no alternatives to the present state of affairs". ${ }^{3}$ Likewise, "just war' apologists for any state's military engagements appeal to a rhetoric of 'what else can be done given the situation?' The problem is that thought here is reduced to the immediacy of the moment, to a form

1 (Žižek 2002, p. 61). Cf. Theodor Adorno, The Culture Industry, 89, cited in (Bauman 2005, p. 140).

2 Theodor W. Adorno, 'Remarks On the Authoritarian Personality' (unpublished 1948), p. 11, cited in (Gordon 2018, p. 71). See (Arendt 1969).

3 (Giroux 2014a, p. 213). 
of reactivity that always comes too late to contribute to the construction of what may otherwise have been an alternative course of action. On the reaction to $9 / 11$, for example, there needs to be a caution lest "moral outrage or public mourning become the occasion for the muting of critical discourse and public debate on the meaning of historical events". ${ }^{4}$ Critical thought should penetrate into any given conditions in order to prevent the 'too late' within which 'there is no alternative'. After all, Arendt observes with critical urgency that we should never forget that there is "no reason to doubt our present ability to destroy all organic life on earth". 5

It is the separation of "knowledge (in the modern sense of know-how) and thought" that Arendt bewails. ${ }^{6}$ The consequences of any such estrangement involve people becoming "the helpless slaves, not so much of our machines as of our know-how, thoughtless creatures at the mercy of every gadget which is technically possible, no matter how murderous it is". ${ }^{7}$ Decisions requiring thought "therefore can hardly be left to the decision of politicians of professional scientists or professional politicians". Arendt's consequent demand is for political thinking, or the agency of thinking-together that contributes to the development of conditions appropriate for the wellbeing of agents with and for one another. The rub, she observes, however, is that "it goes against the very nature of self-interest to be enlightened". 8 In her analysis of the "modern world alienation", this is precisely where she regards professional political decisionism and strategic planning as having ended up -in a self-interest that is unable to think of the public, the common, the project of natalising the world. ${ }^{9}$ Just such a development provides the conditions for being unable to think morally. ${ }^{10}$ In fact, in addition to the "flight ... from the world into the self" come the very labours of the space programme, which can encourage an evasion of earthly responsibility, thereby ordering the imagination towards a "flight from the earth into the universe" ${ }^{11}$ It is this kind of thoughtlessness-toward-self-destruction that provokes Arendt to lament that "the modern world, in which we live today, was born with the first atomic explosions". ${ }^{12}$

Arendt's response, then, involves, among other things, advocating a form of political thinking that educates the kind of critical awareness that can positively contribute to reconstruing action conducive to flourishing or "natality". ${ }^{13}$ This is no straightforward matter that can be handled by glib academic advocacy, or rhetorically fudged in generalised terms. ${ }^{14}$ Appealing to educative depth, Arendt admits that "To expect [self-interested] people, who have not the slightest notion of what the res publica, the public thing, is to behave nonviolently and argue rationally in matters of interest is neither realistic nor reasonable". ${ }^{15}$ In fact, to assume that a modern politics that has largely freed itself from moral reasoning can do this critically natalising work would be both naïve and unproductive.

At least towards the end of the twentieth century, a range of voices chirped from a markedly different sensibility from that of Arendt several decades earlier. With a reference to Francis Fukuyama by way of illustration, Nicholas Lash recognises this, although he does open this paper by citing Ulrich Beck's remark that "Where there is no escape, people ultimately no longer want to think about it". ${ }^{16}$ In fact, in contrast to Fukuyama's earlier mood, it is arguable that the period following the end of the Cold War so far has been punctuated by something of an apocalyptic sensibility, and a securitisation

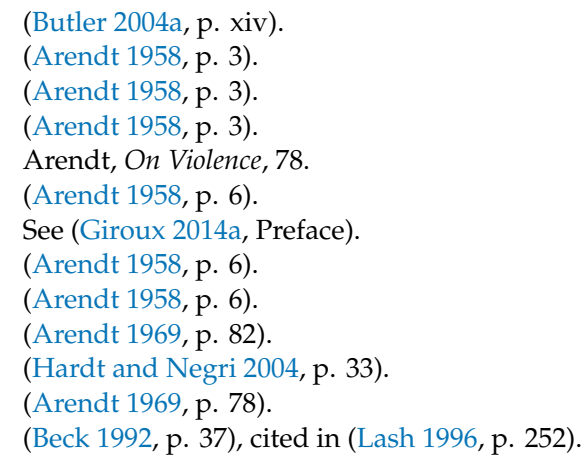


against threat, where the menace is perceived in a quite distinctive way: as subjectivity being imperiled by the threat that otherness is adduced to pose to the self-same subject. In the permanent state of exception during the so-called 'war against terror', its own version of "holy terror", 17

the American public [in particular] has been turned into 'security addicts', ingesting mistrust, suspicion, and fear as the new common sense of a new security state ... Crises become the new rationale for destroying the ideologies, values, and institutions that empower the social contract. The ethos of rabid individualism, hyper-masculinity, and survival of the fittest has created a society of throwaways of both goods and people. The savage ethic of economic Darwinism drives the stories we now tell about ourselves. ${ }^{18}$

Accordingly, where political philosophy has turned towards at least an agonism (even if not a fully formed antagonism) such as that underpinning Thomas Hobbes' political imagination, ${ }^{19}$ the task of compelling a "change [in] the myths we live by" functions to encourage critical resistance for the sake of alleviating many of the conditions that generate unjust suffering. ${ }^{20}$ This would articulate the need for. and possibility of, conversing about the imaginative construction of subjectivities that have the capacity for contesting and surpassing the impoverished visions of contemporary political desire, desire that itself has already been shaped in advance by "the logic of neoliberalism [that] has extended its reach into all domains of life" ${ }^{21}$ Here, for instance, is where Nicholas Lash enables the generation of a theopolitical account that engages in what he calls a "purification of desire". 22 "Christianity is about healing or liberating from sin. It is a therapy, a way of life that releases desire from its bondage, that cures the madness so that desire may once again flow as it was created to do" ${ }^{23}$

Before moving into a testing of the politics of relations within the post-political at Fukuyama's 'end of history' by introducing Samuel Huntington's revisionist political repair, and gesturing towards the shape of a therapy of desire in a theopolitics of hospitality, it is worth recognising the urgency of questions regarding the shape of critical theorising for emancipatory hope. ${ }^{24}$ According to Theodor Adorno and Max Horkheimer, "social freedom is inseparable from [a certain form of enlightened and critical] thought". ${ }^{25}$ The implications of such a claim for repairing political thinking, then, are highly significant. Building upon the insights of critical theorists, Henry Giroux urges that "At stake here is more than a call for reform.... This is a revolution that not only calls for structural change, but for a transformation in the ways in which subjectivities are created, desires are produced, and agency itself is safeguarded as crucial to any viable notions of community and freedom" ${ }^{26}$

Why turn to Fukuyama's 1989 article and Huntington's 1996 book? Can 'beating up on' these old books be in any way productive? To even begin to ask that question would, firstly, be to demonstrate a serious naïveté over the way texts work. It is, after all, odd to imagine the mortification of a text (especially in conceptually intensive academic study), given that any interest it generates involves its revivification. Secondly, and concomitantly, it is certainly evident to anyone paying attention to popular political discourse that both, especially Huntington's, do indeed continue to generate political interest. For instance, in mid 2017, The Washington Post ran an article by Carlos Lozada entitled "Samuel Huntington, a Prophet for the Trump Era" in which it was argued that he "anticipate[d] America's

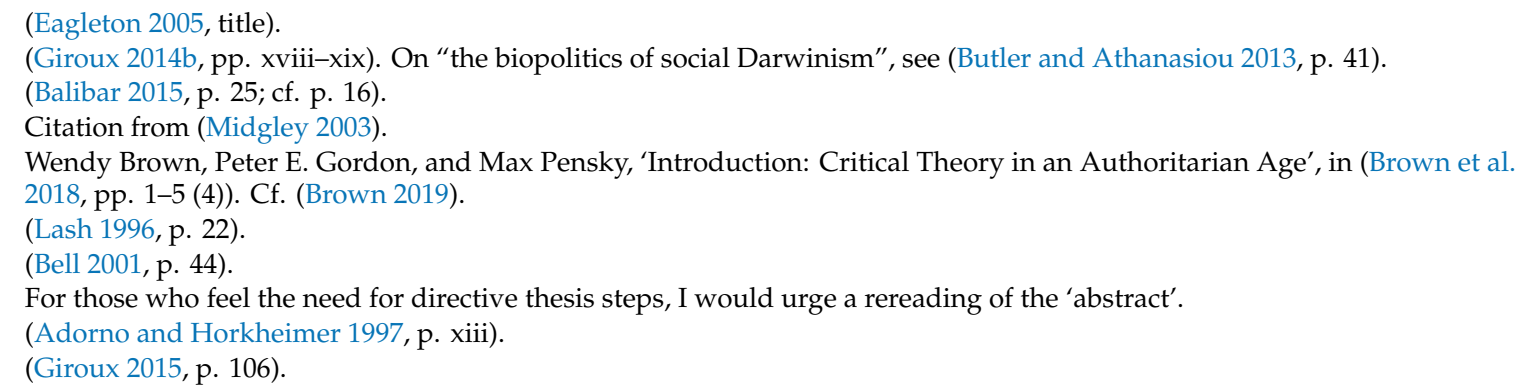


political and intellectual battles-and point to the country we may become" ${ }^{27}$ The occasion was a then recent speech that Trump had delivered in Warsaw, evoking aspects of the clash of civilisations thesis when urging Western nations to "summon the courage and the will to defend our civilization". Lozado proceeds to ominously claim that

Trump's civilizational rhetoric is just one reason Huntington resonates today, and it's not even the most interesting one. Huntington's work, spanning the mid-20th century through the early 21st, reads as a long argument over America's meaning and purpose, one that explains the tensions of the Trump era as well as anything can.

The pre-eminent message of this analysis is that "Trump may believe himself a practical man, exempt from any intellectual influence, but he is the slave of a defunct political scientist". The point has not, in fact, been entirely lost on the political sources close to the President. Almost exactly two years later, the same newspaper carried a story in which National Security Advisor to the President, John Bolton, reportedly had remarked that American-Chinese relations would have "elements of Samuel Huntington's Clash of Civilizations" ${ }^{28}$ In the mind of several journalists, Fukuyama himself appears to have conceded much to Huntington with his recent work Identity: The Demand for Dignity and the Politics of Resentment. ${ }^{29}$ What tends to be missed in discussions of these texts, however, is the very nature of the subject that shapes both of these influential works, so that despite the sense that they had originally been operating with contrasting political accounts, at a crucially regulative point they were assuming a form of conflictuality or antagonism in political subject-positioning.

\section{The Post-Political at the End of History}

With the tearing down of the Berlin Wall in 1989, and the impending collapse of Soviet Communism, Francis Fukyama confidently, and in "triumphalistic notes", declares "the end of history". ${ }^{30}$ The phrase is not original to him, of course. It has been borrowed from G.W.H. Hegel and Karl Marx, albeit for a quite different political effect. By it he does not intend to suggest that the process of history, as the change experienced as time, has ceased. Rather, he refers to the 'meaning' of things or the meaning of 'history' as a process. With this in view, he pictures "history ... as a single, coherent, evolutionary process" ${ }^{31}$ By suggesting that it is this that has come to its end, Fukuyama declares that history has reached its political fulfilment, its ideological goal. Hegel saw this evolution as one of the gradual unfolding of human reason, leading eventually to the expansion of freedom in the world". ${ }^{32}$ And yet, Hegel's dialectic was readily averse to just such forms of closure as Fukuyama's notion of political culmination. Fukuyama recognises this, and consequently admits that his interest is not "in Hegel per se but [more specifically] in Hegel-as-interpreted-by Alexandre Kojève, or perhaps a new, synthetic philosopher named Hegel-Kojève". ${ }^{33}$ That revelation provides the clue to Fukuyama's thesis. The goal, he declares, is "the universalization of Western liberal democracy as the final form of human government". ${ }^{34}$ Quite simply, "the ideal of liberal democracy could not be improved on". ${ }^{35}$ This is supported by the realisation of "liberal principles in economics—-the 'free market' ... [which] have succeeded in producing unprecedented levels of material prosperity". ${ }^{36}$ Fukuyama's apologetic involves predication

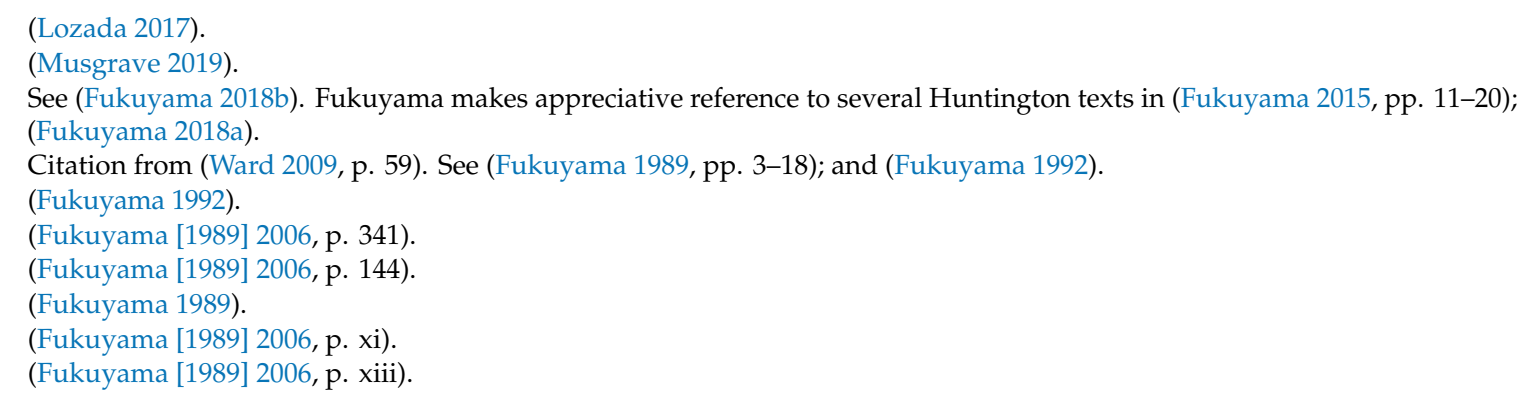


of an economic monism that is well suited for the expansive reach of neoliberal capital and its inclusivity, and the reduction of political "leadership ... [to] models of corporate management". 37

A theopolitical engagement with this material comes from Graham Ward. He argues that Fukuyama is "aware of the tensions in his thesis", and in particular to the continued realities of suffering. ${ }^{38}$ So, the neoliberal apologist acknowledges that "the victory of liberalism has occurred primarily in the realm of ideas or consciousness and is as yet incomplete in the real world. But there are powerful reasons for believing that it is the ideal that will govern the material world in the long run". ${ }^{39}$ Fukuyama's thesis is that while stable liberal democracies do not yet exist worldwide, philosophically speaking, "liberal democracy remains the only coherent political aspiration that spans different regions and cultures around the globe" ${ }^{40}$ And so, unconstrained by Soviet Communism, the future would be characterised by the universal admission and implementation of the superiority of liberal democratic politics and the global economy by regimes throughout the world. Moreover, he concedes that "There is no doubt that contemporary democracies face any number of serious problems, from drugs, homelessness, and crime to environmental damage and the frivolity of consumerism" ${ }^{41}$ Nonetheless, these social "problems were [also] ones of incomplete implementation of the twin principles of liberty and equality on which modern democracy is founded". ${ }^{4}$

Even so, recognising this as a set of pressing problems, and properly attending to the causes and significance of those identified problems are not necessarily the same, and here, Graham Ward's argument that Fukuyama's work here is appropriately complex is much too quick. Not only have critics attacked Fukuyama's optimism, but many have crucially argued that the types of liberal political and economic values he promotes would actually serve to undermine the project of seeking a just society. ${ }^{43}$ For instance, Zygmunt Bauman declares that "Globalization appears to be much more successful in adding new vigour to intercommunal enmity and strife than in promoting the peaceful coexistence of communities". ${ }^{44}$ Accordingly, Fukuyama's vision of civilly-conducted forms of free political and rational economic competition and peaceable "letting prices be determined by market mechanisms" is distinctly unconvincing when reflected in his exceedingly glib claims about both the nature of neoliberal capital and its capacity to refigure all lives for flourishing. ${ }^{45}$ He is unaware of the fact that neoliberalism is a performative rationality, "a governing rationality generating distinctive kinds of subjects, forms of conduct, and orders of social meaning and value". 46 This is the nub of the issue, and here, Wendy Brown's political philosophical critique of neoliberalism is helpful. "Neoliberal rationality", Brown argues, "renders every human being and institution, including the constitutional

\footnotetext{
(Giroux 2014b, p. xix).

(Ward 2009, p. 59).

(Fukuyama 1989).

40 (Fukuyama 1992, p. xiii). On the one hand Fukuyama wants to use empirical affairs by way of justifying his thesis. So, he claims, there has been a "move toward political freedom around the globe" which would have been everywhere accompanied, "sometimes followed, sometimes preceded" by "a liberal revolution in economic thought." On the other hand, the "good news" remains at the level of regulating ideal that cannot be measured against any historical or empirical sets of affairs, a trans-historical ideal. Jacques Derrida complains, "Depending on how it works to his advantage and serves his thesis, Fukuyama defines liberal democracy here as an actual reality and there as a simple ideal. ... Even as we take seriously the idea that a heralding sign or a promise constitutes an irreducible event, we must nevertheless guard against confusing these two types of event. A thinking of the event is no doubt what is most lacking from such a discourse." (Derrida 1994, 62f.)

41 (Fukuyama [1989] 2006, p. xxi).

42 (Fukuyama [1989] 2006, p. xi).

43 The critique of Fukuyama, then, is not that he "had a too-optimistic view of capitalism" as one reviewer of this paper thought it was. To begin with, that would be reductive with regard to the more complex later chapters of his book, never mind failing to pay attention to the focus of my own analysis. The issue of 'optimism' certainly could do with its own critical analysis. For this, I would refer the reader to (Eagleton 2015).

44 (Bauman 2000, p. 192).

45 Citation from (Fukuyama [1989] 2006, p. 97).

46 (Brown 2018), in (Brown et al. 2018, pp. 7-43 (12)).
} 
state, on the model of the firm and hence supplants democratic principles with entrepreneurial ones in the political sphere". ${ }^{47}$

It is this "refashioning of the self in market terms that not only produces a neurotic form of atomisation, but also a predatory culture of indifference of intolerance, cruelty, and abuse" ${ }^{48}$ This issue is crucial. Several critics maintain that procedural analyses fail to engage in the fundamental consideration of "the most basic moral convictions that should govern the development of public policies". ${ }^{9}$ The skin-deepness of a polis without a substantive sense of 'the good' could be little more than a thin peaceableness of ever further fracturing cultures, but at worst contributes to substantive practices of dehumanisation within deterritorialised markets' transvaluation of values. ${ }^{50}$ It is noticeable, therefore, that Fukuyama's claims do not make sense of the production of a growing underclass, a precariat in both the post-industrial West and the industrial non-West. Certainly, in an era of massified socio-cultural distraction and biopolitical conditioning, it would take quite a considerable effort to imagine that this multitude is sufficiently capable of political self-consciousness as a potential revolutionary force. Nonetheless, Marx and Engel's sense that capitalism produces its own mechanisms for radical destabilisation has not lost its timeliness, no matter what Fukuyama blithely generalisingly declares from a reading of the fall of Soviet power to be the case, from a safe distance from the manufacture of suffering, despair, and intensive malcontent. ${ }^{51}$ Furthermore, his claims have not anticipated the appearance of the 'economic' refugee. "[R]efugees", Žižek argues, "are the price humanity is paying for the global economy", "the production of 'redundant people" ${ }^{\prime \prime} .52$

For Fukuyama, nevertheless, the situation is predominantly described in rather harmonious terms. "Technology", he postulates, "makes possible the limitless accumulation of wealth", rather than a situation in which technology continues to accentuate the instability of the fluidity of production, wealth, and the precariousness of work and income; in which accumulation does not occur by dispossessing others and intensively centralising prosperity. ${ }^{53}$ While wealth has indeed been enhanced, so too has personal and national debt. In typically triumphant mood, Fukuyama declares that "Liberal democracy replaces the irrational desire to be recognized as greater than others with a rational desire to be recognized as equal" ${ }^{54}$ This, however, glaringly fails to attend to the competitiveness built into the market system, and the overriding economisation of values, including persons. With the reduction of everything to its exchange value, to the "totalitarian" logic of "the rule of computation and utility" - a dehumanising reduction that Adorno and Horkheimer regard as having been built into the objectifying sensibility of the Enlightenment itself and its own particular form of "the disenchantment of the world"-occurs a demoralising of the political economy. ${ }^{55}$ As Bauman and Donskis argue,

47 Wendy Brown, “'We Are All Democrats Now ... "', in (Brown 2011, pp. 44-57 (47)). Cf. (Brown 2015, p. 27); (Brown 2018, pp. 12-13). The problem is not that things are reduced to their "bare materiality", as John Milbank and Adrian Pabst claim (Milbank and Pabst 2016, p. 3). It is rather the nature of the material relations that are conditioned by a refigured materiality under the terms of neoliberalised capital. Accordingly, the critique requires more to locate neofascism within the logic of the liberal order than Milbank and Pabst provide when they regard it as "travestied post-liberalism" (p. 380). Chantal Mouffe, for instance, "In the case of neoliberalism ... we are dealing with a social formation that articulates a particular form of liberal democracy within financial capitalism." (Mouffe 2018, p. 16; Giroux 2019, chp. 3)

48 (Giroux 2014a, p. 222).

49 (Thiemann 1996, p. 11).

50 (Žižek 2017) impresses the question: is this not the logical outcome of capitalism rather than the by-product of only problematic forms of capitalism that can be better regulated and ordered? This is "the very historical moment when global capitalism no longer needs Western cultural values (egalitarianism, fundamental rights, the welfare state) in order to function smoothly, and is doing quite well with authoritarian 'alternative modernity'." (Žižek 2017, p. 10) For Žižek, the market and its operations are about the flows of power: "the global capitalist legal system itself is, in its most fundamental dimension, corruption legalized. The question of where crime begins (which financial dealings are illegal) is thus not a legal question but an eminently political question, a question of power." (Žižek 2017, p. 15)

51 See (Marx and Engels 1998, pp. 10-11).

52 (Žižek 2016, p. 101; Bauman 2016, p. 3, respectively).

3 (Fukuyama [1989] 2006, p. xiv).

54 (Fukuyama [1989] 2006, p. xx).

55 (Adorno and Horkheimer 1997, pp. 3, 6). "Enlightenment behaves toward things as a dictator toward men. He knows them in so far as he can manipulate them.... In this way their potentiality is turned to his own ends." (p. 9) 
"the consumerist culture thereby transforms every shop and service agency into a pharmacy purveying tranquillizers and anesthetic drugs: in this case drugs intended to mitigate or altogether placate moral, rather than physical pains". ${ }^{56}$ Persons become reducible to not merely statistical units for political rhetoric, or a workforce as the means of production, but units of consumption. It is hardly surprising that, Bauman adds, "The fraudulence of the promised 'trickle-down' effect of opulence at the top has now been laid bare-for everybody to watch helplessly and bewail—but the 'collateral casualties' of the grand deception are here to stay for a long time to come" ${ }^{\prime 57}$ From here he critiques the dismantling of the welfare system and a range of publicly-supported social activities, polices that reflect the evisceration "of social solidarity and communal responsibility ..., the idea of social justice" and the wiping away of "the shame and social condemnation attached to greed, rapacity and ostentatious consumption" through their having "been recycled into objects of pubic admiration and celebrity cult" ${ }^{58}$ The casualties of the process have been variously described by commentators as, for instance, human "waste" and "collateral damage", as "accumulations of waste or junk", and as "disposable" persons produced through "Neoliberalism's disposability machine" imbued with a "logic of a savage market instrumentality and individualization of the social" ${ }^{59}$ What occurs in this, then, is the production, state management of, and disposal of "redundant populations" in order to enhance market efficiency. ${ }^{60}$ That the refugee and the immigration applicant are rendered as problems reflects a deep difficulty. The agential subject has been subjected to an ontologic that atomises subjectivity. Accordingly, the stranger becomes unable to put the self-secure self in question but can herself be reduced to not merely a foreigner, but "the absolute other". ${ }^{61}$

Bauman refers to Beck's image of the zombie in order to refer to the reduction of persons to the precariat and bare life. That is an image developed for critical effect in a double mode by Giroux. On the one hand, Giroux claims, "The apostles of the agitated rich embrace the notion that it is easy to kill the hordes of walking dead-those zombies of the underclass were made mad, desperate, and disposable under casino capitalism ... suggesting that the poor are not difficult to slaughter and forget about" ${ }^{62}$ On the other hand, he equally uses zombie imagery to depict the lack of compassion among the political classes who devour others when necessary without any moral hesitation. This rhetorical flourish provides Giroux with a memorable means for identifying and opposing "a zombie politics that opposes any legislation or policy designed to lessen human suffering and promote economic and social progress". 63 "This is an authoritarianism in which mindless self-gratification becomes the sanctioned norm and public issues collapse into the realm of privatized anger and rage" ${ }^{\prime 64}$

Giroux does recognise that "Unchecked avarice and egotism are not new". 65 That is not a particularly interesting claim, however. What is more interesting is his admission about the recent configuration that normalises and refigures social subjectivities. ${ }^{66}$

The stories a society tells itself are often a measure of how a society imagines itself, how it values democracy, and how it anticipates its future. Such stories become integral not only to how people see themselves, but also how a society determines which lives are worth living, what modes of agency count, what lives matter, and what deaths should be grieved. ${ }^{67}$

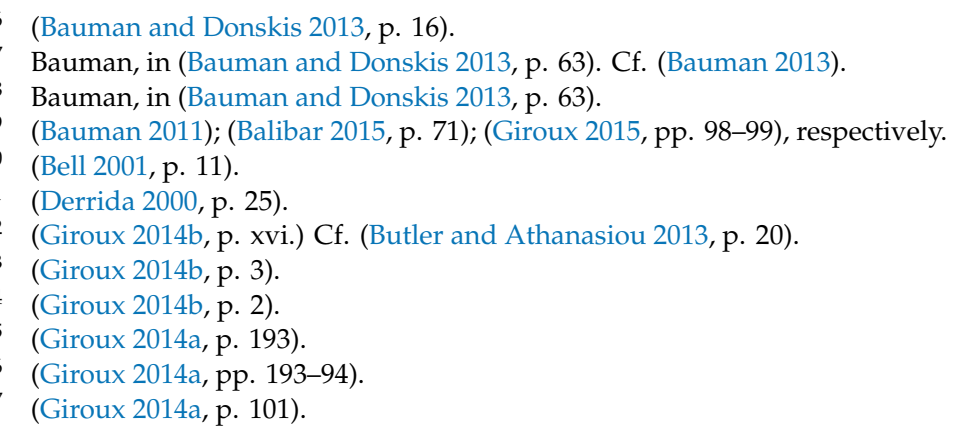


As Bell argues, "the market mediates ... all relations of desire agonistically. Capitalist discipline distorts desire into a competitive force". ${ }^{68}$ Given that this is the case, it is little wonder, then, that numerous political commentators identify the dominant shared social value as being not some common good, but some shared anxiety. For instance, Giroux regards the "eviscerated society" as being united in "shared fears rather than shared responsibilities". ${ }^{69}$ Another commentator puts the matter bluntly, and concerningly for any shared project for constructions of desire through hope: "It is not hope but fear that excites and shapes the cultural imagination of the early twenty-first century". ${ }^{70}$ Anything more than that is seemingly a hindrance to the promotion of self-interest. ${ }^{71}$

The reference to the political in terms of a "friend/enemy" dichotomy is an allusion to the controversial, but nonetheless highly influential, writing of Carl Schmitt. He anticipates the political import of the intensification of the modern economy, and its "onslaught against the [very] political" itself so that "There must no longer be political problems, only organizational-technical and economic-sociological tasks. ... The modern state seems to have actually become what Max Weber envisioned: a huge industrial plant". ${ }^{72}$ Concomitantly, he continues, "The core of the political idea, the exacting moral decision, is evaded" within this reconfiguration of the political. ${ }^{73}$ Schmitt senses, then, a decoupling of the moral engagement and the technical form of the political in his time, and it is that which he seeks to repair in a way that does not succumb to the dictatorial capacity of the momentary intrusion of an occasionalistic moral decisionism. How he does that in The Concept of the Political is through an appeal to the friend/enemy distinction. "[T]he specific political distinction to which political actions and motives can be reduced is that between friend and enemy" ${ }^{74}$ Schmitt resists reducing the enemy to categories of morality (evil), aesthetics (ugliness), or economics (competitor). Instead, enmity may simply emerge from the strangeness of the other: "he is ... the other, the stranger; and it is sufficient for his nature that he is, in a specifically intense way, existentially something different and alien, so that in the extreme case conflicts with him are possible". ${ }^{75}$ Accordingly, the possibility of war from conditions of enmity remains an ever-present threat for which the state requires preparation. This is not, then, the kind of perpetual peace that Kant envisages as providing the proper conditions for rational political action, but rather a negative peace that occurs only in the form of a lack, or the absence of, war. Kant offers a pedagogy for sovereigns, a training in moral understanding for governmental effect. After all, he worries, without this moral cultivation, "the princes first of all have not so much the best for the world in mind but rather the well-being of their state". ${ }^{76}$ Kant's pedagogy involves that which he regards as necessary for the education of everyone: showing "that the inequality of human beings is an institution which has arisen because one man has tried to obtain advantages over another". ${ }^{77}$ The difficulty with this, he concludes, is that educated or enlightened subjects "must rejoice at the best for the world even if it is not to the advantage of their fatherland or to their own gain". ${ }^{78}$

We will need to return to that political binary later, since it is just the antagonistic construal of subjectivity that is at issue in the paper, and the moralising of the friend/non-friend distinction so that the 'they' are 'evil'. ${ }^{79}$ For now, it is important to notice Giroux's connection between this binary politics and the logic of savage capitalism's free market. After all, as Kant recognizes, at least in

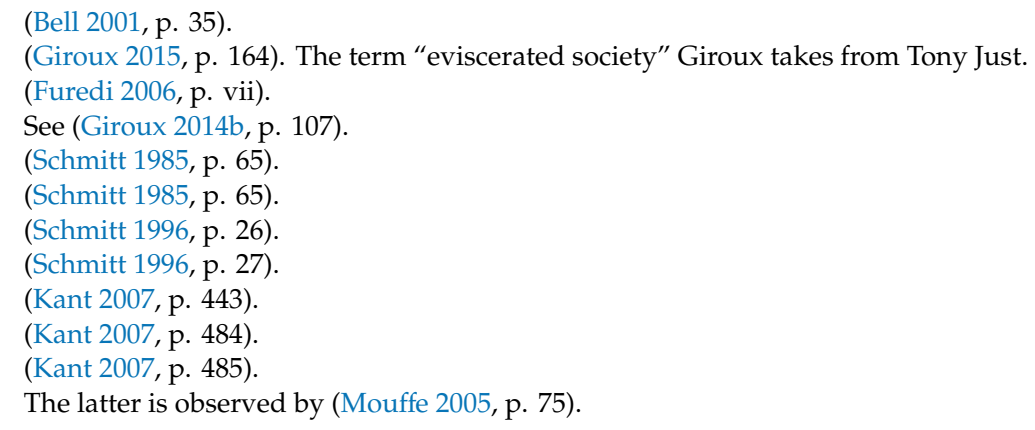


terms of sovereigns, "princes regard their subjects merely as instruments for their own designs". ${ }^{80}$ Consequently, Slavoj Žižek asserts, "It needs to be said that the true threat to our common way of life does not come in the shape of refugees but lies in the dynamic of global capitalism". ${ }^{81}$ The point is that what some call the new all-pervasive "empire", or capital in its neoliberal configuration, in particular has refigured subjectivity itself. ${ }^{82}$ Its "dominion is not merely an economic affair", but instead "is ontological". ${ }^{83}$

Where Wendy Brown's sense is of the "unleashing of the power of capital as an unchecked world power", Fukuyama's optimism is partly funded by a belief in the liberal education system that "creates the conditions for democratic society" by liberating "people from prejudices and traditional forms of authority". ${ }^{84}$ This too is substantially complacent. No form and performance of education is politically innocent and neutral, and the formal education systems have always taken shape in, and through, hegemonic political values and desires as a biopolitical mechanism for the disciplining of subjects in "the social therapeutics currently deployed by neoliberal governmentality". ${ }^{85}$ So Max Pensky declares that thoughtlessness is the substance of social discipline. "Stupidity in this socially constructed sense is not just compatible with education but implies it". ${ }^{86}$ That Fukuyama continues to use traditional terms that have moral significance, such as liberation and freedom from "traditional forms of authority" (by which, he presumably means irrational and unjust authority), is glaring evidence that he has failed to notice the burgeoning inverse proportion between the accentuating neoliberal technique of the educational telos and the growing demoralisation within the mechanics of proceduralism that was intensified early in the 1990s. The citizen subject has been steadily replaced by the consumptive and entrepreneurial subject of "globalising neoliberalism". ${ }^{87}$ Accordingly, within the neoliberalised education system, "Schools are corporate-sponsored training camps for producers and consumers", 88 and with finances dictating the quality of access to the centres of corporate training excellence, and indeed the very nature and experience of time, it is only a bizarrely bourgeois and inattentive naïveté that can even begin to claim with a straight face that "The universalism and formality that characterizes the rule of law in liberal democracies does provide a level playing field on which people can compete, form coalitions, and ultimately make compromises". ${ }^{89}$

\section{Uncivilly Clashing Cultures}

According to Étienne Balibar, on the one hand, the "oneness of humanity exists in practical, not ideal, fashion as a world population in immediate communication with the totality of itself"..$^{90}$ Moreover, humanity is united under the globality of the threat posed to its futurity in the anthropocene. Nonetheless, with "nationalism ... increasingly becoming a function of racism", and with the "multiplication of internal borders and a universalization of 'thresholds of tolerance', it is no longer possible in any way to imagine and symbolize universal fraternity as the ideal unity of the human species". That means that the supposed 'end of history' has not advanced global co-operation and political harmony but has led, Chantal

\footnotetext{
(Kant 2007, p. 442).

(Žižek 2016, pp. 19-20).

Franz Hinkelammert, cited in (Bell 2001, p. 10).

(Bell 2001, p. 12).

(Fukuyama [1989] 2006, p. 116).

(Butler and Athanasiou 2013, p. 103).

6 Pensky, 'Radical Critique and Late Epistemology: Tocqueville, Adorno, and Authoritarianism', in (Brown et al. 2018, pp. 85-124 (117)).

87 Kenneth Surin, 'Rewriting the Ontological Script of Liberation: On the Question of Finding a New Kind of Political Subject', in (Surin 2005, pp. 240-66 (245)).

88 (Bell 2012, p. 77). Cf. (Giroux 2019, chp. 5); (Brown 2015, chp. 6); (McDowell 2015, pp. 221-36).

89 (Fukuyama [1989] 2006, p. 117). On the reconfiguration of time within the intensified moment of capital, see the conceptual redevelopment of David Harvey's work on the post-industrial in (McDowell 2011, pp. 299-321; McDowell 2019); Scott Kirkland, 'Creative, Apophatic Hopes: Temporality, Resonance Machines, and Entangled Misty Futures', in (Kirkland 2018, pp. 162-74). (Balibar 2015, p. 15).
}

90 
Mouffe recognises, "to the explosion of a multiplicity of new antagonisms". ${ }^{91}$ And these are bound up with appeals to practices inducing national nostalgia for an imagined past. $^{92}$

An influential and still-exemplary text in this conflictual mould, functioning in many ways as something of a counter-thesis to Fukyama's vision, is that of Samuel Huntington's highly influential, but equally controversial The Clash of Civilizations. ${ }^{93}$ If Fukuyama's The End of History and the Last Man exhibits a pronounced political thoughtlessness about the shape of liberal democracy in neoliberalised conditions, Huntington's substantive political response to this neoliberal account, built on something of a thoughtless nationalised nostalgia as it is, introduces a further set of difficulties. Even under the burgeoning post-statist condition of capital, he refuses to reimagine the value of state sovereignty. ${ }^{94}$ The danger is that Huntington becomes an example of what Hardt and Negri criticise as the Geheimrat, "the secret advisor of the sovereign". 95 For this pair of critics, The Clash of Civilizations is driven not by any political notion of co-operative globality, but rather by the losses of global power and order that have occurred at the end of the Cold War that "had been a stable principle that had organized nation-states into allies and enemies, thus defining global order". ${ }^{96}$ It is, in other words, a "reactionary" text. ${ }^{97}$

Fukuyama, for his part, warns of the danger of overestimating "the degree to which we [viz., he and Huntington] differ in our interpretation of the world".$^{98}$ Yet Huntington regards Fukuyama as having neglected to anticipate that the end of the Cold War would not resolve conflicts but would, in many ways, relocate and intensify them. "The one harmonious world paradigm", then, "is clearly far too divorced from reality to be a useful guide in the post-Cold War world" ${ }^{99}$ In contrast to the hegemonic globalisation of the Western Enlightenment which he regards as underpinning Fukuyama's vision, Huntington articulates "the multicivilizational character of global politics" so as to recognise differences without having to destructively impose one's own imperialistically. 100 "The philosophical assumptions, underlying values, social relations, customs, and overall outlooks on life differ significantly among civilizations". ${ }^{101}$ In fact, he contends, appropriately recognising this contributes to the generation of peacefulness, and this process is especially pertinent to the maintenance of what he regards as the uniquely Western civilisation that is experiencing substantial shifts in power to its detriment. Even here, while hedging his statements with appeals to civilisational multipolarity, Huntington announces in a throwaway comment that "The world is in some sense two ... a Western one and a non-Western many". ${ }^{102}$ Nonetheless, he argues, "clashes of civilizations are the greatest threat to world peace, and an international order based on civilizations is the surest safeguard against world war". ${ }^{103}$

Ward both appreciates what he exaggeratedly reads as a book that "focuses on what is particularly absent from Fukuyama's Western secularist perspective: the powerful and global resurgence of religion". ${ }^{104}$ "Huntington does show that the struggle for a new world order has religion at its very

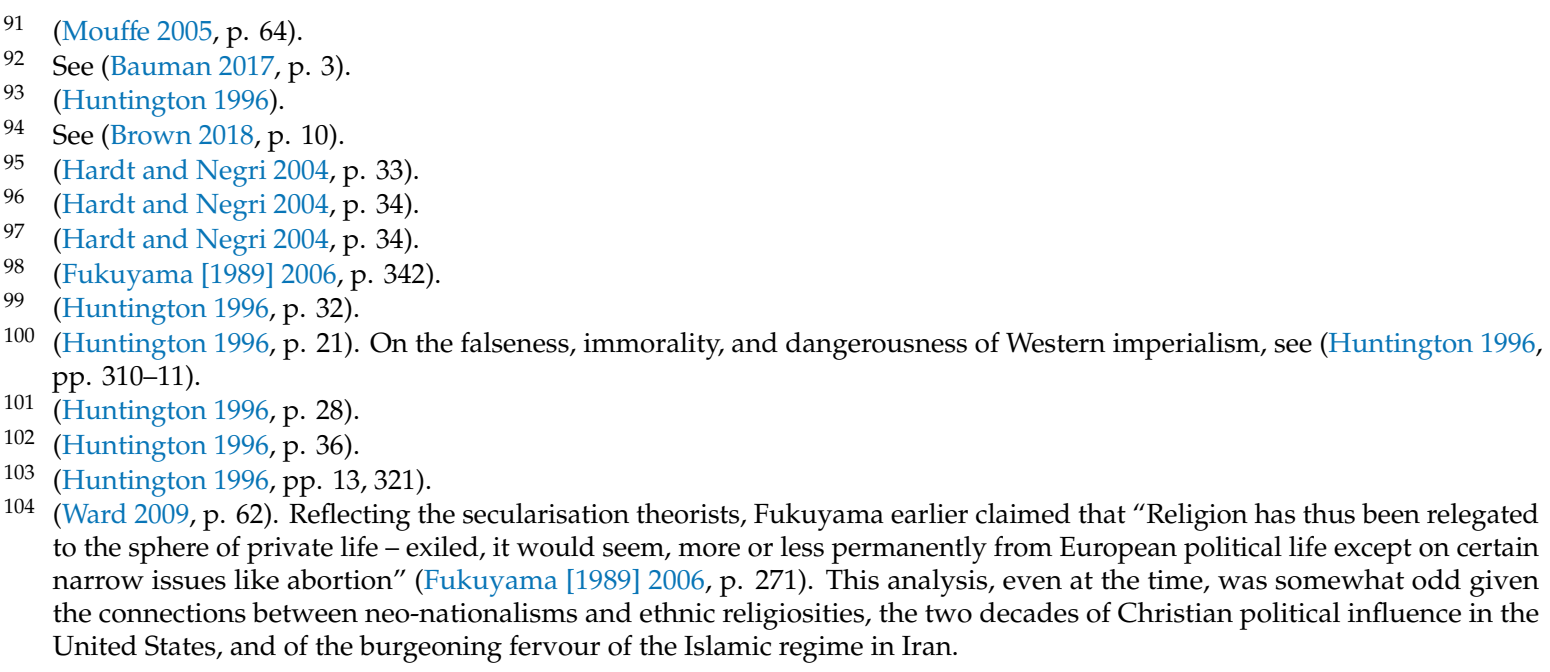

104 (Ward 2009, p. 62). Reflecting the secularisation theorists, Fukuyama earlier claimed that "Religion has thus been relegated to the sphere of private life - exiled, it would seem, more or less permanently from European political life except on certain narrow issues like abortion" (Fukuyama [1989] 2006, p. 271). This analysis, even at the time, was somewhat odd given the connections between neo-nationalisms and ethnic religiosities, the two decades of Christian political influence in the United States, and of the burgeoning fervour of the Islamic regime in Iran. 
heart. Religion is central to the contemporary era of world politics". ${ }^{105}$ Whatever 'religion' is, however, it remains inseparable from a range of cultural values and biopolitical configurations that overlap in manifold and complex ways: nationalism, gender, race, economic status, and so on. Ways of inhabiting ancient traditions are subject, then, to an array of contingent matters and a variety of concretely particular conditions. Given that that is so, it makes no sense to speak of 'religion' being central to any political form, or to the violence of geopolitical agonisms. According to Joerg Rieger, for instance, "violence is rooted in deep political and economic structures that play off people against each other, often using religion as a pretext.... Investigations of how religions or civilizations clash without taking into account how these clashes are tied to political and economic power differentials are not only deficient but profoundly misleading". ${ }^{106}$ Nonetheless, Ward attempts to use the nebulously named something called 'religion' in order to contest Huntington's geo-particularisations, in particular the Christian species of 'religion'. "[T] he major religions are no longer bound to territory and the rule of cuius regio, eius religio". ${ }^{107}$ This is as puzzling as it is incoherent. 'Major religions' tend to take a particular shape when in the United States, with its perpetuation of the national project and its maintenance, more so than in, for example, parts of the Republic of Ireland that have a more distinctly European outlook. ${ }^{108}$ After all, it should hardly require articulation that modern nation-states have assumed the role of primary identity-markers, and have reinforced that through a set of biopolitical tactics, as Balibar argues. ${ }^{109}$

Even leaving aside that simplistic assumption, and important questions of the meaningfulness of a term like 'religion', 110 Ward implies that such transnational 'religions' may well offer resources for hope by virtue of their transnational realities. Accordingly, he declares that "religion may be the hope for the making of a new world order rather than the dry tinder awaiting ignition". 111 It may well be that such traditions may indeed contribute to the construction of hope for a new world in which all may be supported to flourish. But that is for a whole set of reasons that considerably thicken the suggestion (of course, Ward's book does later thicken his odd argument in some ways) that it has to do with geographic borderlessness, lest McDonalds or Coca Cola be regarded as sources of liberation due to their lack of national circumscription.

Huntington's case is built on a largely essentialised, sealed off, and coherently describable set of 'civilisations'. For instance, he claims that "The survival of the West depends on Americans reaffirming their Western identity and Westerners accepting their civilization as unique not universal and uniting to renew and preserve it against challenges from non-Western societies". ${ }^{112}$ In this way, Hardt and Negri argue, he "remains stuck in the old paradigm of world order, seeking to configure new clusters of nation-states, now in civilizations, to substitute for the cold war blocs". ${ }^{113}$ Huntington's analysis thereby deepens the disengagement between traditions, peoples, civilisations, and so on. It is one thing to articulate that identity is the construction of difference, but entirely another to maintain that

105 (Ward 2009, p. 142).

107 (Ward 2009, p. 144).

108 Ward makes a further odd claim regarding the unity between the 'major traditions' that does not take seriously the way, for instance, Americanised Christianities are as committed qua Christians to the American version of capital as they are to 'God and nation': "what unites the faithful communities of these different religious traditions is a common enemy - the godlessness of cultures driven by secular ideals, capitalist rapaciousness, decadent levels of wastage, and a hypocrisy that points to the abuse of human rights abroad and closes its eyes to the inadequate provision for the socially vulnerable at home." (pp. 144-45)

109 (Balibar 2015, p. 111).

110 Vincent J. Miller, for example, claims that "Generalized talk of 'religions traditions' is itself consonant with commodity abstraction." (Miller 2003, p. 10) William T. Cavanaugh makes the case that "religion is not a transcultural and transhistorical feature of human societies... 'Religious' and 'secular' as they have been constructed originally in Europe and subsequently the rest of the world are not neutral descriptive terms, but are rather prescriptive. They help create the worlds they purport to describe." ['The Invention of the Religious-Secular Distinction', in (Cavanaugh 2014, pp. 105-28 $(105,120)]$

111 (Ward 2009, p. 144).

112 (Huntington 1996, pp. 20-21).

113 (Hardt and Negri 2004, p. 35). 
the differential has to be that of self-enemy. Why should some lives, those overlapping with one's own civilisation, be grievable while those of the 'alien', the strange other, are not? As Judith Butler maintains, "if a life is not grievable, it is not quite a life; it does not qualify as a life and is not worth a note", an obituary. ${ }^{114}$ What moral grounds are there for ensuring one's own 'civilisation's' survival over and against that of another? Butler's analysis is pointed: "It is not just that some humans are treated as humans, and others are dehumanized; it is rather that dehumanization becomes the condition for the production of the human to the extent that a 'Western' civilization defines itself over and against a population understood as, by definition, illegitimate, if not dubiously human". ${ }^{115}$ Huntington's assumption is one that is based on a political mythos that emerges largely from Hobbes via Schmitt. His political ontology betrays too much of the binarity of modernity's anthropological commitments. As Hobbes urged, "Let us consider men ... as if but even now sprung out of the earth, and suddenly, like mushrooms, come to full maturity, without all kind of engagement to each other" ${ }^{116}$ Yet, it must be asked, even if subject-differentiation is the cause of conflict under certain conditions, in and of itself, does it have to be? What are the conditions that violate anything from intensive cohabitation, through to the lack of conflict provided by any disapproving toleration, or indifferent avoidance? ${ }^{117}$ Here, Hardt and Negri critically observe, Huntington

has conjured up the phantasm of these civilisations to find in them a grand schema that rearranges the friend-enemy division that is basic to politics. Those who belong to our civilisation are our friends; other civilisations are our enemies.... Spinoza aptly called this conjuring up of enemies and fear superstition, and such superstition, he knew well, will always lead to the ultimate barbarity of perpetual war and destruction ...

A discrete set of civilisations, what might be described with Balibar as "the fetichized figure of an 'us' reduced to absolute homogeneity", secured further by the borders of geographic circumscription, distinctly limits possibilities for non-violent encounter, and curtails those possibilities that are conducive to mutual understanding, and even friendship. ${ }^{118}$ Particularly under certain conditions, the resultant ignorance of the other has pronounced implications. Under conditions, for instance, of eroded trust and enhanced mutual suspicion, Bauman argues that "the 'strangeness' of strangers is bound to deepen and to acquire ever darker and more sinister tones", and thereby reduce the capacity for cohabitation. ${ }^{119}$ The crucial question is one that Hardt and Negri put to Huntington's geopolitical proposals: "if one were to accept that the identities of the global population are really defined by the civilizations that Huntington indicates, or some similar civilizations, then the civilizations themselves could serve as a representational basis for a global assembly or parliament" ${ }^{120}$ If Huntington is a reflection of the political philosophy of a Hobbesian Schmitt, then why should the question be one only of how to best manage violent conflict (civil war being the founding rationale for Hobbes' reimagining sovereignty and political order, projected back into an ontological condition of the 'state of nature'), rather than a question of whether relations can be reconceived beyond violence and counterviolence? ${ }^{121}$ For Hardt and Negri, a global state of conflict cannot be solved by the localised nation-states but by a more

114 (Butler 2004a, p. 34).

115 (Butler 2004a, p. 91).

116 (Hobbes 1966, Vol. 2, p. 109). Cf. (Eagleton 2018, p. 2).

117 On the violence of toleration, see (Brown and Forst 2014). "[W]hat tolerance does is mask the powers that have actually produced these differences as conflictual in the first place" [Brown, in (Brown and Forst 2014), p. 62] "[I]n our own societies, is not the multiculturalist notion of tolerance, whose fundamental value is the right not to be harassed, precisely a strategy to keep the intrusive neighbour at a proper distance?" [Slavoj Žižek, Eric L. Santner, and Kenneth Reinhard, 'Introduction', in (Žižek et al. 2005, pp. 1-10 (3)]

118 Citation from (Balibar 2015, p. 61).

119 Bauman, in (Bauman and Donskis 2013, p. 104).

120 (Hardt and Negri 2004, pp. 294-95).

121 See (Eagleton 2018, p. 3). 
properly co-operative globality expressed as "A new global form of sovereignty". ${ }^{122}$ As Bauman argues, global problems of "waste and injustice ... have acquired planetary dimensions", and thereby necessarily require global solutions, and therefore a form of thinking and critical planning that Lash describes as a "global imagination". ${ }^{123}$ "However hard and thorny that task may prove to be, it is imperative and urgent, because for a planet of universal interdependency it is, literally, a matter of (shared) life or (joint) death". ${ }^{124}$

Of crucial concern with Huntington's civilisational essentialism is not only the problem of the failure of the rhetoric to describe affairs, but the implications it also has. What, for instance, does it mean for the realities of 'civilisational' geo-fluidity? Huntington's account functions as a way of contesting the en- and inter-culturation of any host society generated by immigration on language, culture, the philosophical grounding of value commitments in sets of belief claims, and ethnicity. Difference as différance lies not merely at some romanticised geographic border, but pervades societies within those statist borders. At one point, he claims that "conflicts between rich and poor are unlikely because, except in special circumstances, the poor countries lack the political unity, economic power, and military capability to challenge the rich countries". ${ }^{125}$ Among other things, this statement betrays Huntington's archaic thinking in statist terms. Does he not imagine, as Marx and Engels did, the potential for violence against the hoarders of wealth within any given nation state? The Communist appeal to the formation of an international proletariat was a recognition that in matters of injustice, political control, and the violence against populations ordered towards impoverishment as an unskilled workforce for capital's production, national borders did not matter. Nonetheless, Huntington's mythos also has the capacity for generating borders within nation states around cultural particularities such as race, 'religion', and so on. "Peoples and countries with similar cultures are coming together. Peoples and countries with different cultures are coming apart". ${ }^{126}$ Huntington means by this that similar ethnic and civilisational groupings are uniting in contradistinction to those wherein there are differences (such as in the former Yugoslavia). However, what the implications might be in civic, rather than ethnically ordered, nation states, wherein there are manifest cultural differences pervading the society, Huntington does not here consider. How, in other words, does this work in a country such as Australia in which the indigenous populations are themselves products of colonial displacements, but yet are forced to cohabit with not only the invading British originating population, but with more recent immigrants from Italy, Greece, India, Lebanon, Egypt, Sudan, China, and so on? How does it work as a civilisation in Huntington's sense when ethnic groupings themselves (leaving aside the further complicating factor of inter-racial births) do not unifiedly share commitments to traditions such as Confucianism, Christianities, Islams, Hinduisms, Buddhism, an array of 'New Age' liquid spiritualities, or secular humanism? Huntington has simplistically described matters, even though he is not entirely unaware of identifying particularities deeper than what he otherwise tends to allow for in his geopolitical story:

In coping with identity crisis, what counts for people are blood and belief, faith and family. People rally to those with similar ancestry, religion, language, values, and institutions and distance themselves from those with different ones.... [E]veryone has multiple identities which may compete with or reinforce each other: kinship, occupational, cultural, institutional, territorial, educational, partisan, ideological, and others. ${ }^{127}$

Yet from here he proceeds to proclaim that "In a world where culture counts, the platoons are tribes and ethnic groups, the regiments are nations, and the armies are civilizations". ${ }^{128}$

\footnotetext{
122 (Hardt and Negri 2004, p. 239).

123 (Bauman 2005, p. 145); (Lash 2004, p. 52).

124 (Bauman 2011, p. 25).

125 (Huntington 1996, p. 33).

126 (Huntington 1996, p. 125).

127 (Huntington 1996, pp. 126, 128)

128 (Huntington 1996, p. 128).
} 
Furthermore, there are pronounced implications for territorial nation-states' arbitration over matters of access to inclusion, and thereby over matters of real life/welcome and death/exclusion, despite the deterritorialising fluidity of capital. With the production of economically displaced people and political refugees there is the pressure for 'civilisational' protection to exclude them from national welcome in the name of defending one's own (whether that be the supposed economic protectionism of work availability, or the morally even grubbier protection of some nebulous race-essentialised culture).

With the construction of primary forms of identification at stake, the point is, then, not merely that Huntington's essentialising claims are evidently obscurantist, rhetorical masks of a more complex set of affairs that cannot be ossified by a systematising comprehensiveness of description. It is rather that, as the construction of a way of construing self and other, that it is far from a set of politically innocent observations, even if such a thing were possible, but is instead distinctly dangerous.

One particularly evident way in which this appears is in his discussion of Islam. Huntington's titular phrase had originally been coined by Bernard Lewis in 1957 in an alarmist prediction that by the end of the twentieth century Europe would be Islamic. While The Clash of Civilizations appeared half a decade before 9/11, its reading of Islam nevertheless explosively contributed to the political narrative of the destructive event as invoking "a conflict of the West against Islam ... . In this context, in fact, the hypothesis of a clash of civilizations seems to be not so much a description of the present state of the world but rather an explicit prescription, a call to war, a task that the 'West' must realize". ${ }^{129}$

Huntington describes an impending clash of global value systems between the West and the Middle East anchored in conflicting religious belief structures, particularly where Western versions are politically domesticated products of the Peace of Westphalia of 1648 whose polis is nationally governed in a way that conflicts with Islamic theopolitics. Of course, the narrative assumes that there is something of a singularity called 'Islam' that contests modernity, and an equally uniform 'Western modernity'. Likewise, it problematically assumes that there is a single 'West' that is cohesively united as a civilisation behind a coherent understanding of truth, meaning and purpose. In reality, even the United States is politically fractured with regard to its own determinatively identifying political myth of American exceptionalism. As Edward Said acknowledges, "Partly because of empire, all cultures are involved in one another; none is single and pure, all are hybrid, heterogeneous, extraordinarily differentiated and unmonolithic". ${ }^{130}$ According to Huntington's generalisingly "reductive and brutal" mood, ${ }^{131}$ "The underlying problem for the West is not Islamic fundamentalism. It is Islam". ${ }^{132}$ This kind of claim strengthens the hand of those secularising forces that now intensify their attempts to keep religious traditions out of the public setting - whether that be the publics of politics, economics, or education.

Richard Kearney argues, "In an age crippled by crises of identity and legitimation, it would seem particularly urgent to challenge the polarization between Us and Them". ${ }^{133}$ Here, the category of the monstrous to mythically depict the alien, stranger, foreigner, is telling. "'Monsters'”, Kearney declares, "signal the borderline experiences of uncontainable excess, reminding the ego that it is never wholly sovereign". ${ }^{134}$ The way he ethically sets this up is through Girard's projective notion of scapegoating so that we "attempt to simplify our existence by scapegoating others as 'aliens'. So doing, we contrive to transmute the sacrificial alien into a monster, or into a fetish-god. But either way, we refuse to recognize the stranger as a singular other who responds, in turn, to the singular otherness in each of us. We refuse to acknowledge ourselves-as-others". ${ }^{135}$ As Girard himself proclaims, the victim as monster is "hard to recognize as a victim because he is totally monstrous", and, simultaneously,

\footnotetext{
29 (Hardt and Negri 2004, p. 34).

130 (Said 1993, p. xxix).

131 (Ward 2009, p. 143).

132 (Huntington 1996, p. 217).

133 (Kearney 2003, p. 5).

134 (Kearney 2003, p. 3).

135 (Kearney 2003, p. 5).
} 
the violence of the victimisers' is elided by the "permanent concealment of its [viz., scapegoating persecution's] origins in collective violence". ${ }^{136}$ This means that the one who is othered is conventionally positioned in a particular way that dehumanises by virtue of being denied a human face on which human vulnerability and intelligible motivation become in any way perceptible. The visual construct, the literal human de-facing or effacing of the human visage, reinforces a binary with a strict border, and as a result, the violent purge of monstrous otherness is conducted as a moment of ontological hygiene and social therapy. In fact, the political pharmakon thereby complacently justifies otherwise morally illegitimate and reprehensible actions such as brutal torture, unilateral action, pre-emptive strike, and the ungrieving for civilian collateral damage within the undifferentiated massification of monstrousness. Under these conditions, the point is to challenge and contest the conditioning political imagination, and of the production of antagonistic subjectivity. As Mouffe claims, the "main task" of hegemony-transformative practices "is the production of new subjectivities and the elaboration of new worlds" so as to "subvert the existing configuration of power". ${ }^{137}$ And this, Mouffe urges, has to occur on "an alternative 'anti-essentialist' approach as to grasp the multiplicity of struggles against different forms of domination". 138

\section{Hospitality Without Taking Hostages}

As was cited earlier, according to Huntington, "It is human to hate. For self-motivation and motivation people need enemies: competitors in business, rivals in achievement, opponents in politics". ${ }^{139}$ The absurdity of conflating terms like competition, rivalry, and opposition with terms such as hate and enemies does not deserve comment. What does require unpacking is the further essentialism on display: "it is human to hate". Huntington here does not specify that this is the way some people operate, or that it is not uncommon to see rivalry being borne out in conjunction with 'hatred'. No, it is human to hate! Žižek claims that "we feel free because we lack the very language to articulate our unfreedom". ${ }^{140}$ Huntington's human is unfree, but the frustrations of experiencing that unfreedom are culturally channelled into a language of hate (against immigrants, ethnically different, religiously different, people from other nations, supporters of a rival football club, and so on). As Butler warns, "If we take the field of the human open for granted, then we fail to think critically and ethically about the consequential ways that the human is being produced, reproduced, and deproduced". ${ }^{141}$ What Butler's work presses here is the notion of the self as a subject that appears, that comes to be in its inviolable depth only self-referentially, arbitrarily will-full, and as a convenient fiction for securing a self-subsisting and self-possessive ontological monadicness and ethical individuation. In contrast, selfhood-as-subjectivity is a taking place, a coming to be that refuses to steal away the multiple contextual interdependencies of its constitutive relations, and to render intersubjectivity a self-deprivating negation or slight on its self.

What might a radically different construal look like? Is there an approach that can serve a positive pluralisation of agents, but one which does not either take the form of "An idealized view of human socialibility" or an essentialising inevitability ${ }^{142}$ At one point in her anti-essentialised pluralistic demoi-cratisation of the rational undecidability of the political, Mouffe refers to Derrida's account of "hostipitality", wherein there is the precarity of the hospes/hostis. ${ }^{143}$ Picking up on the political and social significance of this notion, Bauman, for his part, suggests that the appeal to traditions of neighbourliness may be productive here. He approvingly appeals to Freud to the effect that "The call to 'love thy

136 (Girard 1986, pp. 35, 100).

137 (Mouffe 2013, pp. 87, 105).

138 (Mouffe 2018, p. 2).

139 (Huntington 1996, p. 130).

140 (Žižek 2002, p. 2).

141 (Butler 2004b, pp. 36-37).

142 Citation from (Mouffe 2005, p. 2).

143 (Mouffe 2013) p. 41), referring to (Derrida 2002). 
neighbour as thyself ${ }^{\prime} \ldots$ is one of the fundamental precepts of civilized life" ${ }^{144}$ Civilisation, the critical suggestion is, functions well under positive practices of welcome, embrace, love, and unravels under the weight of the conflictuality of self-interest expressed in, among other things, binary oppositions that ground ignorance, fear, hatred, and violence. The difficulty, Bauman's Freud suggests, is that "nothing else runs as strongly counter to the original nature of man". ${ }^{145}$ The appeal to "original nature", and later to "the instincts set by nature", here is troubling, given the phenomenological incapacity of describing that to which thought has no access, although it could serve as a critical reference to Hobbes' account of the state of nature, and therein be deconstructed as a projection of the socially constructed account of 'experience' of culturally formed instinct that it is. ${ }^{146}$ If it is difficult to imagine human nature without socially conditioned language of competition, conflict, antagonism, and violence, it is precisely in traditions of neighbourliness that a critical gesture of significance for reimagining social formation is provided beyond an arbitrary assertion that this is what emerges as civilising in a Kantian sense. In this regard, Bauman presses Freud harder with regard to practices of cohabitation: "Accepting the precept of living with one's neighbour is the birth of humanity. All other routines of human cohabitation, as well as their predesigned or retrospectively discovered rules, are but a (never complete) list of footnotes to that precept" ${ }^{\prime 147}$ In order to head off any suggestion that the commandment is a moral one, where by morality is meant something less than the political, Bauman continues, that it "renders morality a part, perhaps a conditio sine qua non, of survival". And by survival, Bauman means not the individuated production from self-interest as much as global human perpetuation, in fact "the survival of humanity in the human". ${ }^{148}$ Accordingly, Bauman asserts that the commandment "challenges and defies the meaning of survival set by nature, and of that self-love which protects it". 149

More explicitly in response to Huntington's clash-thesis, Richard Kearney believes that it is by advocating "the ethic of hospitality" that the political takes a non-antagonistic shape. By this ethic, and its ordering as a hermeneutic, Kearney argues that "the stranger is precisely the one who reminds us - not as enemy but as host- that the self is never an autonomous identity but a guest graciously hostaged to its host". ${ }^{150}$ This notion of a reminder, and the "hermeneutic of hospitality" that Kearney puts it to use for, is designed on rather limited noetic terms. It is an interpretive device that lacks the political punch of an ontological reconfiguration of identification and practicing to cultivate responsible citizens as neighbours. While Kearney does oppose what he regards as Habermas' sublation and liquefaction of "the religious roots of hospitality into a discourse ethics of rational norms and universalisable laws", his approach nonetheless shifts into the universalisable ethical away from the specificity of the religiously concrete. ${ }^{151}$ Accordingly, he speaks generalisingly of "religious difference [that] bears the potential for welcoming aliens", and even seeks to prescribe what should be the case for "every religion". 152

A different approach is evident in Nicholas Lash's important work. In a lecture entitled 'Cacophony and Conversation', Lash argues for the need to resist reductive, fragmenting and alienising forms of identification through what he calls a "global imagination". 153 The very "necessary condition of the achievement and fostering of such imagination", he maintains, is that "humankind could, in some measure, be brought into something like a common conversation". ${ }^{154}$ The ordering of the intercommunicatively significant response is Christological. This permits him to gesture towards

144 (Bauman 2003, p. 77).

145 Freud, Civilization and Its Discontents, cited in (Bauman 2003, p. 78).

146 Second citation from (Bauman 2003, p. 79).

147 (Bauman 2003, p. 78).

148 (Bauman 2003, p. 78).

149 (Bauman 2003, p. 79).

150 (Kearney 2011, pp. 101-11 (101)).

151 (Kearney 2011, p. 102).

152 (Kearney 2011, p. 105).

153 (Lash 2004, chp. 3).

154 (Lash 2004, p. 52). 
a Christologically performative hospitality that provides the setting for relearning an anti-violent politics of conversation. So, elsewhere, Lash argues that "sharing a common human nature is a matter of relationship, and not merely of biological affinity". ${ }^{155}$ That relationship takes on a particular form, the form of a sheer divine gift, and its consequent formative conditions are those that enable Lash to declare that "Christianity is a school for the production of persons in relation to the unknown God through discipleship of the crucified". ${ }^{156}$

In an earlier work, Lash announced that "The heart and centre of the christian message concerns the humanisation (or incarnation) of God". ${ }^{157}$ In fact, he goes on to argue, it "is about the liberating humanisation of God". 158 This entails that all things take their rise from, are grounded in, and have their raison d'être from the Self-givingness of God's economy with the world. They are, then, spoken forth as the gifts of the Self-communicativeness of God, the God whose very Self-giving of the creature takes the distinctive form of hosting a generous embrace of all things in and through the inclusive primordiality of Jesus the Christ, the constitutive act of being in the unconditionality of "absolute hospitality" ${ }^{159}$ Alluding to the Prologue of the Fourth Gospel, Lash declares: "God does not say many things, but one. God speaks the one Word that God is and, in that one Word's utterance, all things come into being, find life and shape and history and, in due time, find fullest focus, form and flesh in Mary's child". ${ }^{160}$ Or, as Bonhoeffer puts it, "God's compassion on a sinner must and can be heard only as God's final word; for otherwise it is not heard at all. ... There is no word of God that goes beyond His mercy". 161

For Lash, this divine saying one thing is a reading rule, a hermeneutical guide to scriptural reasoning. However, it is considerably more than that, since reading the scriptures is itself ordered towards the living out of the life of discipleship for the witness to the world. That entails, then, that it is a reading rule for all things as relationally situated within the gifting will of the creative and recreative God. Dietrich Bonhoeffer argues that "The commandment of God is something different from what we have so far referred to as the ethical. It embraces the whole of life". ${ }^{162}$ As "gift", this happens in such a way as to remove God's creatures from the reductive evaluations of calculative rationality. ${ }^{163}$ All things belong to the focused giving forth of God's communicative agency, an activity of divine poiesis that ends in creaturely flourishing, that has its focal intensification in all things reaching their fulfilling culmination in the eschatological action of God. Anticipating the end of that road is given shape, for Lash, by the road to Emmaus:

At the end of the road, the context is one of hospitality: they [viz., the travelers who were formerly disciples of the executed Jesus] invite the stranger in. He is the guest; they are his hosts. ... What they discover, when they are at table, is that it is they, in fact, who are the guests, the recipients of hospitality; and that it is he who is the host. ... What they 'recognized,' as they began to see the point, was his new presence as the bread he broke, the life he shared, at the beginning of this new conversation which is, for all eternity, uninterruptible. ${ }^{164}$

155 (Lash 1988, p. 255).

156 (Lash 1988, p. 258). Lash terms the conditioning form or shape "grammar". "We require some such grammar for our pedagogy, because all the pressures - outside and within- both pressures applied by the structures and mind-sets of individualism and collectivism alike, and pressures derived from fear and egotism, homelessness, ambition, and despair, incline us to opt for 'irrelation': to treat persons as things, and to bind the mystery of God into the It-world by mistakenly identifying some feature of the world - some induvial, some nation, some possession, some dream, some project, some ideal - with divinity, with the 'nature' of God. We require some 'set of protocols against idolatry,' against the manifold forms of the illusion that the nature of God lies within our grasp." (Lash 1988, pp. 260-61)

157 (Lash 1968, p. 3).

158 (Lash 1968, p. 6).

159 (Derrida 2000, p. 25).

160 (Lash 2004, p. 66).

161 (Bonhoeffer 1964, p. 100).

162 (Bonhoeffer 1964, p. 244).

163 Citation from (Bonhoeffer 1964, p. 103).

164 (Lash 2004, pp. 70-71). 
It is precisely within such a universalistically inclusivist imagining that it becomes problematic to talk of 'the religious' if by that is meant something distinct from the common recognition of the political. According to José Casanova, entering into the public sphere changes the character of religion, resulting in a conforming of it to public norms. ${ }^{165}$ True, the church's witness was evidently distorted by being formed within the hegemony of National Socialist disciplining of its desire, for instance. This fact, along with innumerable other examples, demands of the theologians that they "become aware of how theology has worked and continues to work in the interests of this or that system of power". 166 However, that was not the consequence of the pre-existing church coming into a formed public that logically requires its conformity. Rather, it was the consequence of a polis that had become dislocated from the healing work of the Gospel, and of a Gospel that had itself become evacuated of its redemptive capacity. As Bonhoeffer argues, "there is no real possibility of being a Christian outside the reality of the world and that there is no real worldly existence outside the [materially incorporative] reality of Jesus Christ. There is no place to which the Christian can withdraw from the world". ${ }^{167}$ Consequently, the theologian can expend considerable energy in critiquing improper or disordered understandings of the relation of church and world, church and the polis, and therein refuse the terms that can in any shape or form evacuate God's redemptive agency from any space or feature of materiality itself. For Lash, "Much of the irrelevance and ineffectiveness of christianity in the modern world can be traced to a failure, on the part of christians, to ask the right questions about the relationship of their christian belief to this world in which they live". ${ }^{168}$ The point is well made by William Cavanaugh that the very religious-secular "distinction as we know it is not simply a fact about the world; it articulates and makes possible a contingent set of social arrangements that are not inevitable". ${ }^{169}$

Lash is certainly concerned about a range of binary distinctions. For instance, when explaining the creedal reference to Jesus being verus deus et verus homo, he announces that the trickiest word is the 'and'. ${ }^{170}$ After spending time dislocating 'God' from 'being' so that what it is meant by 'God' cannot, properly, have to do with an ontologically competitive entity or member of a genus, he announces that God is not an object competing for our affections. "We do not love God plus man: we love man with a love which is of God, we love our brother in God. We do not talk about God plus man: we talk about man with a knowledge which is of God, we know our brother in God". ${ }^{171}$ Among other things, the statement entails that God does not love reactively, and therefore the giving of God's love does not, accumulatively dominating, demand a completion of a divine lack by creatures. As the event of a Self-grounded plenitude, God, as love, gives creatures their creatureliness as a pure gratuity. Lash's claim involves a way of saying that God is the ground and grammar of living, the shape that living well (or for flourishing) takes. So, theology "is only about God and man in the sense that it is about being human in a new way. It is about the recovery, and the discovery, of human brotherhood that springs from the love that God has for us, poured into our hearts through Christ Jesus our Lord". ${ }^{172}$ The Gospel, when couched in these terms, is about God's making all things together for a symbiotic flourishing within mutual care. Wellbeing cannot morally involve any evacuation of the self's responsibility for

165 (Casanova 1994, pp. 135, 207), described in (Miller 2014, pp. 162-96 (189)).

166 (Williams 2000, p. 8).

167 (Bonhoeffer 1964, p. 172). Cf. (Williams 2018).

168 (Lash 1968, p. 2).

169 Cavanaugh, 'The Invention of the Religious-Secular Distinction', 105. "To speak of a 'resurgence of Islam' as an instance of the 'resurgence of religion' distorts because many scholars and practitioners of Islam do not consider it to be a religion, precisely because it does not make the kind of distinction between 'religion' and 'secular' phenomena like 'politics' that is integral to the Western concept of 'religion'." (p. 106) In fact, "Religion and politics were not separated; they were inventions of the modern era." (p. 116)

170 (Lash 1968, p. 5).

171 (Lash 1968, p. 12). "There is no relation to men without a relation to God, and no relation to God without a relation to men, and it is only our relation to Jesus Christ which provides the basis for our relation to men and to God." (Bonhoeffer 1964, p. 192)

172 (Lash 1968, pp. 11-12). 
the other. As Žižek argues, then, “one should renounce striving for one's own (spiritual) salvation as the highest form of salvation". ${ }^{173}$

Immanuel Kant announces that "True worship of God consists in acting according to God's will'. ${ }^{174}$ The question, of course, is what content these terms 'God' and 'will' have. The sense of an irreducible sociality, which discursively constitutes self-with-others, is lost on Kant. In his essay 'The End of All Things', he puts the matter rather negatively: "the only thing which could perhaps be called human wisdom is acting in a way which is not visibly contrary to the idea of that [divine] wisdom". 175 Although he continues to have a strong sense of what 'nature' is in a way that is subverted by a theology that discerns it "only in relation to Jesus Christ Himself", Kant, in his 'Lectures on Pedagogy', at least, recognises that the enlightened human nature is not a given, but is disciplined, cultivated, civilised, and moralised, and therefore that the subject has a formative history that requires collaboration with others. ${ }^{176}$ "The human being is the only creature that must be educated.... Discipline or training changes animal nature into human nature.... Training is therefore merely negative, that is to say, it is the action by means of which man's tendency to savagery is taken away.... The human being needs care and formation. ... The human being can only become human through education". ${ }^{177}$ Education, then, for Kant has a significant civilising function, provided by schooling for humanisation, or rather for humanisation on its way to full flowering in moralisation since, Kant argues, human being "by nature ... is not a moral being at all; he only becomes one when his reason raises itself to the concepts of duty and law" ${ }^{178}$ The responsibility is even taken not merely for negotiating current conditions, but with a view to planning for future generations. "[C]hildren should be educated not only with regard to the present but rather for a better condition of the human species that might be possible in the future" ${ }^{\prime 179}$ At least Kant attempts to refuse any conflictuality within the realisation of formed subjectivity that renders a lack, a dispossession as giving up and away, in the many's working towards disparate ends: "The child must be shown that it can only reach its goals by letting others also reach theirs" ${ }^{180}$ Even so, it does not take long for the rhetoric of mutuality and co-operation to disappear as Kant articulates the ultimate end in desocialisedly individuated terms. In a confusion of a form of co-dependent spontaneity and pure atomised autonomy, he argues that the child "is cultivated so that it may one day be free, that it, so that it need not depend on the care of others". ${ }^{181}$

Lash, in contrast to Kant, recognises that the Christian tradition of neighbourliness at least grounds socially transformative human agency theologically. It has its ground and grammar within the Being-in-action of the God whose love takes an ex-centrically creative form, and therefore takes its shape as a proper participation within the Good that is the redemptiveness of divine healing action for all things. That means that the communities of 'saints', to appeal to Edith Wyschogrod's ethical category for understanding how moral subjects are made, are less Kant's civilising or humanising of savage animals, than the divinely telic schools of discipleship whose pedagogical therapy is socially re-humanising only under the conditions of the social destructiveness of subjects. ${ }^{182}$ Bonhoeffer uses this ontology of divinely gifting ad extra in the grounding calling, to contest ethics, by which he means the rational decisionism of the individualised moral subject. The subject, he argues, "is the chosen one,

173 Žižek, 'Neighbors and Other Monsters', 141. Kant regards "religion ... not combined with morality" as "a superstitious cult" (Kant 2007, p. 481). Superstitious worship, Kant argues, involves praises that are "an opiate for the conscience of such people and a cushion on which it is supposed to sleep peacefully." (p. 482)

174 (Kant 2007, p. 482).

175 (Kant 1996, p. 228).

176 Citation from (Bonhoeffer 1964, p. 122).

177 (Kant 2007, pp. 437-39).

178 (Kant 2007, p. 479).

179 (Kant 2007, p. 442).

180 (Kant 2007, p. 447).

181 (Kant 2007, p. 448).

182 (Wyschogrod 1990). 
who can no longer choose, but has already made his choice in his being chosen in the freedom and unity of the deed and will of God". 183

The claims of the Gospel, couched in the irreducibly hospitable presence of the redeeming God as pure grace, refuses to concede that any feeling of freedom (Žižek's image) or choosing-as-freedom (Bonhoeffer's image) can be suitably rooted in an ontological commitment to a primordial liberal freedom-for-oneself, intensified by neoliberalism's reconfiguration "of freedom's meaning" as "wholly with the pursuit of private ends", or an intensive freedom-to-be-without-others. ${ }^{184}$ Flourishing is social, rooted in the making-social of Christic action, and therefore 'freedom' to be other than who one is in Jesus Christ as hospitable neighbour mystifies the reality of our condition rather than encouraging appropriate praxis or natalising thoughtfulness. In Christ, this sociality, then, is contoured, given shape as the very groundedness of humanity in, with, and under the form of God's human performance as incarnated presence to all things in Jesus Christ, and perennially-made contemporaneousness in the power of the Spirit. The humanisation of God is, irreducibly, the condition for determining what human subjectivity is, and its performativity is one of deep neighbouring as those who are given within the strangely gracious neighbouring of God to everything that God has made. The Christian, then, cannot echo any effort to explain away the unjust sufferings of others, but instead participates in the witness to the politics of God's redemptive work that irreducibly enacts a justly humanising healing. In such a world, the Christian witness obtains a distinctively interruptively interrogatory hue. As Gregory Jones recognises, "There will be, and have been, social orders in which to embody the genuine virtue of justice ... is to put oneself at odds with the 'common life' of one's culture and that culture's understanding of justice". 185

\section{Conclusions}

Susanne Kappeler makes a stark claim:

War does not suddenly break out in a peaceful society; sexual violence is not the disturbance of otherwise equal gender relations. Racist attacks do not shoot like lightning out of a non-racist sky, and the sexual exploitation of children is no solitary problem in a world otherwise just to children. The violence of our most commonsense everyday thinking, and especially our personal will to violence, constitute the conceptual preparation, the ideological armament and the intellectual mobilization which make the 'outbreak' of war, of sexual violence, of racist attacks, of murder and destruction possible at all. ${ }^{186}$

Some help with the implications of what this means is provided by a claim of Giroux regarding the 'war against terror' in the 'state of exception' when he observes pedagogical configurations by social expectations and public ideologies. "A permanent state of war inevitably relies on modes of public pedagogy that influence willing subjects to abide by its values, ideology, and narratives of fear and violence" ${ }^{187}$ Voices of despair may offer their assertions of impending doom, unimpeded by thought that is conducive to hoping for an alternative beyond neoliberal hegemony, the disposing of waste persons, and the devastation of environmental conditions (it is precisely through the critical engagement with two accounts that appear quite different on the surface, in Fukuyama and Huntington, that this paper has been predominantly concerned). Nonetheless, while Bauman avers that "Humanity

183 (Bonhoeffer 1964, p. 18). This can be utilised to contest the naïve romanticised 'authentic self' (see, e.g., Zygmunt Bauman, in (Bauman and Raud 2015, p. 33)).

184 Citation from (Brown 2018, p. 13).

185 (Jones 1990, p. 7).

186 (Kappeler 1995, p. 9).

187 (Giroux 2014a, p. 50). 
is in crisis", well-ordered and responsible critical thought recognises that "there is no exit from that crisis other than solidarity of humans". ${ }^{188}$

In whatever way that works for the array of traditions within a recognizably pluralised world, for a particular route within Christian theology, it is as an eschatological horizon, a Christic envisioning of humanity in a cohabitive responsibilisation and other-recognition, a performative concretion of a co-humanity that is given or grounded in the poietic embraciveness of the hospitable God, that Christians, at least, are schooled in, to adapt Raymond Williams' terms, "unlearning the inherent dominative mode". ${ }^{189}$ The Christian traditions, then, cannot echo any effort to explain away the unjust sufferings of others, but instead participate in the witness to the politics of God's redemptive work that irreducibly enacts a justly humanising healing beyond the borders of tribalistic identarian politics. On the contrary, at their best, ${ }^{190}$ they can function for thought as "the irritant that can prevent the human world from simply settling down with mutually exclusive and competing tribalisms". ${ }^{191}$ To cite Fukuyama's more recent book, "The rise of identity politics in modern liberal democracies is one of the chief threats that they face", and it is this that is threatening to "doom ourselves to continuing conflict" unless we can work to provide an alternative. ${ }^{192}$

To appeal to practices of 'friendship' as being conducive to re-envisioning thought, however, might appear somewhat glib, especially when the notion is captured within a privatising logic. Yet Stanley Hauerwas usefully explains that friendship is far more than a "metaphor for understanding our relation with God; it is in effect a crucial exercise for learning what it means to have our lives bounded by God's love" ${ }^{193}$ It shapes the kinds of reciprocity that does not abjectly capitulate to forms of domination that fail the other in the event of 'recognition', and thereby it regulates "what kind of selves we need to be in order to live in harmony with others". ${ }^{194}$ A vison of the ontologically asymmetrical neighboured-neighbourliness overflows with a critically transfigurative capacity for co-operative support and the mutuality of responsible action that grounds the agency of subjects. Such remains crucial to schooling a witness to just social healing, within which comes the mitigation of possible antagonisms and processes of dehumanising domination, and the reconstrual of social subjects and their recognisability. The point is that, here, agency has as its discursive conditions a constructive vision of co-operative embrace, rooted in a claim about the citationality or addressedness of all things within the plenitudinousness of gift, and the mutuality of social responsibility. Elsewhere, this has been described as "the potential for a counter-praxis as the responsible life given in theologically ordered identity-determinative practices of embodied hospitality to the stranger ... that 'shatters the fiction that the subject, the performer, of all ethical conduct is the isolated individual'". 195 And as Miroslav Volf argues, "no one should ever be excluded from the will to embrace, because, at the deepest level, the relationship to others does not rest on their moral performance and therefore cannot be undone by the lack of it". 196

188 (Bauman 2016, p. 19). The point is picked up by Žižek: “Advocates of capitalism often point out that, in spite of all the critical prophecies, capitalism is overall, from a global perspective, not in crisis but progressing more than ever - and one cannot but agree with them. Capitalism thrives all around the world (more or less), from China to Africa. It is definitely not in crisis - it is just the people caught in this explosive development that are in crisis. This tension between overall rapid growth and local crises and misery is part of capitalism's normal functioning: capitalism renews itself through such crises." (Žižek 2017, p. 23)

189 (Williams 1958, p. 376).

190 And this is one of several reasons for the rhetorical hesitation in the paper's reparative 'gesture' since there is an identifiable multiplicity of Christian practices and beliefs that are not conducive to what the paper is developing as a theopolitical pharmakon.

191 (Williams 2000, p. 237). For a recent discussion of what cannot be characterised as 'the best' exemplification of Christian commitment to global flourishing, see (Bell 2020).

192 (Fukuyama 2018b, p. xvi).

193 Stanley Hauerwas, cited in (Burrell 2000, p. 53).

194 Volf, 21. Cf. (Eagleton 2018, p. 2).

195 (McDowell 2013), citing (Bonhoeffer 1964, p. 195).

196 (Volf 1996, p. 85). 
Of course, to engage hopefully in this neighbourly performance is to enact a therapy for the hopeful imagination so as to unlearn the thoughtlessness of politically despairing forms of identity politics, such as those rooted in sacralised arrangements of desire that reflect dominant ethnic identifications, or the 'Christianisation' of Blut und Boden beyond the redemptive remaking of God's diverse people together, or even forms of selfhood characterised by the intensification of individuated consumptive desire. Donskis claims that "We live in a world without alternatives". ${ }^{197}$ The point of the reparative theopolitical gesture, then, is to indicate the practice of thought that moves beyond the inherent conflictuality of neoliberal capital (Fukuyama) and the framing of political civilisation (Huntington), and therein to resist despair and witness to where traditions of hopeful hospitality continue to exist at least to some degree, in these "dark times" of crisis (Bauman) of "the public in peril". ${ }^{198}$

Funding: This research received no external funding.

Conflicts of Interest: The author declares no conflict of interest.

\section{References}

Adorno, Theodor W., and Max Horkheimer. 1997. The Dialectic of Enlightenment. Translated by John Cumming. London and New York: Verso.

Arendt, Hannah. 1958. The Human Condition. Chicago and London: The University of Chicago Press.

Arendt, Hannah. 1969. On Violence. Orlando, Austin, New York, San Diego and London: Harcourt.

Balibar, Étienne. 2015. Violence and Civility: On the Limits of Political Philosophy. Translated by G. M. Goshgarian. New York: Columbia University Press.

Bauman, Zygmunt. 2000. Liquid Modernity. Cambridge, Oxford and Malden: Polity.

Bauman, Zygmunt. 2003. Liquid Love: On the Frailty of Human Bonds. Cambridge, Oxford and Malden: Polity.

Bauman, Zygmunt. 2005. Liquid Life. Cambridge and Malden: Polity.

Bauman, Zygmunt. 2011. Collateral Damage: Social Inequalities in a Global Age. Cambridge and Malden: Polity.

Bauman, Zygmunt. 2013. Does the Richness of the Few Benefit Us All? Cambridge and Malden: Polity.

Bauman, Zygmunt. 2016. Strangers at Our Door. Cambridge and Malden: Polity.

Bauman, Zygmunt. 2017. Retrotopia. Cambridge and Malden: Polity.

Bauman, Zygmunt, and Leonidas Donskis. 2013. Moral Blindness: The Loss of Sensitivity in Liquid Modernity. Cambridge and Malden: Polity.

Bauman, Zygmunt, and Leonidas Donskis. 2016. Liquid Evil: Living with TINA. Cambridge and Malden: Polity. Bauman, Zygmunt, and Rein Raud. 2015. Practices of Selfhood. Cambridge and Melden: Polity.

Beck, Ulrich. 1992. Risk Society: Towards New Modernity. London: Sage.

Bell, Daniel, Jr. 2001. Liberation Theology After the End of History: The Refusal to Cease Suffering. London and New York: Routledge.

Bell, Daniel M., Jr. 2012. The Economy of Desire: Christianity and Capitalism in a Postmodern World. Grand Rapids: Baker.

Bell, Daniel M., Jr. 2020. Trump as Mirror for the Church: Death and Despair, Hope and Resurrection of the Church. Religions 11: 107. [CrossRef]

Bonhoeffer, Dietrich. 1964. Ethics. Edited by Eberhard Bethge. London: Collins.

Brown, Wendy. 2011. "We Are All Democrats Now ... ". In Democracy in What State? Edited by Giorgio Agamben, Alain Badiou, Daniel Bensaid, Wendy Brown, Jean-Luc Nancy, Jacques Ranciere, Kristin Ross and Slavoj Žižek. New York: Columbia University Press, pp. 44-57.

Brown, Wendy. 2015. Undoing the Demos: Neoliberalism's Stealth Revolution. New York: Zone Books.

Brown, Wendy. 2018. Neoliberalism's Frankenstein: Authoritarian Freedom in Twenty-First Century "Democracies". In Authoritarianism: Three Inquiries in Critical Theory. Chicago and London: The University of Chicago Press.

197 Leonidas Donskis, in (Bauman and Donskis 2016, p. 1). 
Brown, Wendy. 2019. In the Ruins of Neoliberalism: The Rise of Antidemocratic Politics in the West. New York: Columbia University Press.

Brown, Wendy, and Rainer Forst. 2014. The Power of Tolerance: A Debat. Edited by Luca Di Blasi and Christoph F. E. Holzhey. Wien-Berlin: Verlag Turia + Kant.

Brown, Wendy, Peter E. Gordon, and Max Pensky, eds. 2018. Authoritarianism: Three Inquiries in Critical Theory. Chicago and London: The University of Chicago Press, pp. 45-84.

Burrell, David B. 2000. Friendship and Ways to Truth. Notre Dame: University of Notre Dame Press.

Butler, Judith. 2004a. Precarious Life: The Powers of Mourning and Violence. London and New York: Verso.

Butler, Judith. 2004b. Undoing Gender. London and New York: Routledge.

Butler, Judith, and Athena Athanasiou. 2013. Dispossession: The Performative in the Political. Cambridge and Malden: Polity.

Casanova, José. 1994. Public Religions in the Modern World. Chicago: University of Chicago Press.

Cavanaugh, William T. 2014. The Invention of the Religious-Secular Distinction. In At the Limits of the Secular: Reflections on Faith and Public Life. Edited by William A. Barbieri Jr. Grand Rapids: William B. Eerdmans, pp. 105-28.

Derrida, Jacques. 1994. Specters of Marx: The State of the Debt, the Work of Mourning, and the New International. Translated by Peggy Kamuf. New York and London: Routledge.

Derrida, Jacques. 2000. Of Hospitality: Anne Dufourmantelle Invites Jacques Derrida to Respond. Translated by Rachel Bowlby. Stanford: Stanford University Press.

Derrida, Jacques. 2002. Hostipitality. In Acts of Religion. London and New York: Routledge, pp. 356-420.

Eagleton, Terry. 2005. Holy Terror. Oxford and New York: Oxford University Press.

Eagleton, Terry. 2015. Hope Without Optimism. Charlottesville: University of Virginia Press.

Eagleton, Terry. 2018. Radical Sacrifice. New Haven and London: Yale University Press.

Fukuyama, Francis. 2006. The End of History and the Last Man. New York, London, Toronto and Sydney: Free Press. First published 1989.

Fukuyama, Francis. 1989. The End of History? The National Interest 16: 3-18. Available online: http://www.cla.wayne. edu/polisci/krause/Comparative/SOURCES/fukuyama.htm (accessed on 5 January 2001).

Fukuyama, Francis. 1992. The End of History: By Way of an Introduction. Available online: http://www.csf. colorado.edu/mirrors/ma...t/philosophy/works/us/fukuyama.htm (accessed on 5 January 2001).

Fukuyama, Francis. 2015. Why Is Democracy Performing So Poorly? Journal of Democracy 26: 11-20. [CrossRef]

Fukuyama, Francis. 2018a. 'Huntington's Legacy', 14.2 (27 August 2018). Available online: https://www.theamerican-interest.com/2018/08/27/huntingtons-legacy/ (accessed on 23 March 2020).

Fukuyama, Francis. 2018b. Identity: The Demand for Dignity and the Politics of Resentment. New York: Farrar, Straus and Giroux.

Furedi, Frank. 2006. Culture of Fear Revisited: Risk-taking and the Morality of Low Expectation, 4th ed. London and New York: Continuum.

Girard, René. 1986. The Scapegoat. Translated by Yvonne Freccero. Baltimore: The John Hopkins University Press.

Giroux, Henry A. 2014a. The Violence of Organized Forgetting: Thinking Beyond America's Disimagination Machine. San Francisco: City Lights Books.

Giroux, Henry A. 2014b. Zombie Politics and Culture in the Age of Casino Capitalism, 2nd ed. New York: Peter Lang.

Giroux, Henry A. 2015. Dangerous Thinking in the Age of the New Authoritarianism. London and New York: Routledge.

Giroux, Henry A. 2017. America at War with Itself. San Francisco: City Lights Books.

Giroux, Henry A. 2018. The Public in Peril: Trump and the Menace of American Authoritarianism. New York and London: Routledge.

Giroux, Henry A. 2019. The Terror of the Unforeseen. Los Angeles: The Los Angeles Review of Books.

Gordon, Peter E. The Authoritarian Personality Revisited: Reading Adorno in the Age of Trump. In Authoritarianism: Three Inquiries in Critical Theory. Edited by Wendy Brown, Peter E. Gordon and Max Pensky. Chicago and London: The University of Chicago Press, pp. 45-84.

Hardt, Michael, and Antonio Negri. 2004. Multitude: War and Democracy in the Age of Empire. New York: Penguin Books.

Hobbes, Thomas. 1966. Philosophical Rudiments Concerning Government and Society. In The English Works of Thomas Hobbes. Edited by W. Molesworth. Darmstadt: Wissenschaftliche Buchgesellschaft, vol. 2. 
Huntington, Samuel P. 1996. The Clash of Civilizations and the Remaking of World Order. New York: Simon \& Schuster. Jones, L. Gregory. 1990. Transformed Judgment: Toward a Trinitarian Account of the Moral Life. Eugene: Wipf \& Stock. Kant, Immanuel. 1996. Religion and Rational Theology. Translated and Edited by Allen W. Wood, and George Di Giovanni. Cambridge and New York: Cambridge University Press.

Kant, Immanuel. 2007. Anthropology, History, and Education. Edited by Günter Zöller and Robert B. Louden. Cambridge: Cambridge University Press.

Kappeler, Susanne. 1995. The Will to Violence: The Politics of Personal Behaviour. Cambridge: Polity.

Kearney, Richard. 2003. Strangers, Monsters, and Gods: Interpreting Otherness. London and New York: Routledge.

Kearney, Richard. 2011. Beyond Conflict: Radical Hospitality and Religious Identity. In Philosophy and the Return of Violence: Studies from this Widening Gyre. Edited by Nathan Eckstrand and Christopher Yates. New York and London: Continuum.

Kirkland, Scott. 2018. Creative, Apophatic Hopes: Temporality, Resonance Machines, and Entangled Misty Futures. In Creation and Hope: Reflections on Ecological Anticipation and Action from Aotearoa New Zealan. Edited by Nicola Hoggard Creegan and Andrew Shepperd. Eugene: Pickwick, pp. 162-74.

Lash, Nicholas. 1968. His Presence in the World: A Study in Eucharistic Worship and Theology. London and Sydney: Sheed and Ward.

Lash, Nicholas. 1988. Easter in Ordinary: Reflections on Human Experience and the Knowledge of God. London: SCM Press.

Lash, Nicholas. 1996. The Beginning and End of Religion. Cambridge: Cambridge University Press.

Lash, Nicholas. 2004. Holiness, Speech and Silence: Reflections on the Question of God. Aldershot and Burlington: Ashgate.

Lozada, Carlos. 2017. Samuel Huntington, A Prophet for the Trump Era. The Washington Post, July 19. Available online: https://www.washingtonpost.com/news/book-party/wp/2017/07/18/samuel-huntington-a-prophetfor-the-trump-era/ (accessed on 23 March 2020).

Marx, Karl, and Friedrich Engels. 1998. The Communist Manifesto. Translated by Samuel Moore. London: The Merlin Press.

McDowell, John C. 2011. Feastings in God at Midnight: Theology and the Globalised Present. Pacifica 23: $299-321$. [CrossRef]

McDowell, John C. 2013. "Hospitality" at the End of Religion. The Bonhoeffer Legacy: Australasian Journal of Bonhoeffer Studies 1: 79-103.

McDowell, John C. 2015. God at the End of Higher Education: Raising the Telos of the University Higher. Colloquium 47: 221-36.

McDowell, John C. 2019. Theology and the Globalized Present: Feasting in the Presence of God. Minneapolis: Fortress Press.

Midgley, Mary. 2003. The Myths We Live By. London and New York: Routledge.

Milbank, John, and Adrian Pabst. 2016. The Politics of Virtue: Post-Liberalism and the Human Future. London and New York: Rowman \& Littlefield.

Miller, Vincent J. 2003. Consuming Religion: Christian Faith and Practice in Consumer Culture. New York and London: Continuum.

Miller, Vincent J. 2014. Media Constructions of Space, the Disciplining of Religious Traditions, and the Hidden Threat of the Post-Secular. In At the Limits of the Secular: Reflections on Faith and Public Life. Edited by William A. Barbieri Jr. Grand Rapids: William B. Eerdmans, pp. 162-96.

Mouffe, Chantal. 2005. On the Political. London and New York: Routledge.

Mouffe, Chantal. 2013. Agonistics: Thinking the World Politically. London and New York: Verso.

Mouffe, Chantal. 2018. For A Left Populism. London and New York: Verso.

Musgrave, Paul. 2019. John Bolton is Warning of a "Clash of Civilizations" with China. Here are the Five Things You Need to Know. (18 July 2019). Available online: https:/www.washingtonpost.com/politics/2019/07/18/ john-bolton-is-warning-clash-civilizations-with-china-here-are-five-things-you-need-know/ (accessed on 23 March 2020).

Rieger, Joerg. 2018. Jesus vs. Caesar: For People Tired of Serving the Wrong God. Nashville: Abingdon Press.

Said, Edward W. 1993. Culture and Imperialism. London: Chatto \& Windus.

Schmitt, Carl. 1985. Political Theology: Four Chapters on the Concept of Sovereignty. Translated by George Schwab. Chicago and London: The University of Chicago Press.

Schmitt, Carl. 1996. The Concept of the Political. Translated by George Schwab. Chicago: University of Chicago Press. 
Surin, Kenneth. 2005. Rewriting the Ontological Script of Liberation: On the Question of Finding a New Kind of Political Subject. In Theology and the Political: The New Debate. Edited by Creston Davis, John Milbank and Slavoj Žižek. Durham and London: Duke University Press, pp. 240-66.

Thiemann, Ronald F. 1996. Religion in Public Life: A Dilemma for Democracy. Washington, DC: Georgetown University Press.

Volf, Miroslav. 1996. Exclusion and Embrace: A Theological Exploration of Identity, Otherness, and Reconciliation. Nashville: Abingdon Press.

Ward, Graham. 2009. The Politics of Discipleship: Becoming Postmaterialistic Citizens. Grand Rapids: Baker. Williams, Raymond. 1958. Culture and Society, 1780-1950. London: Chatto \& Windus.

Williams, Rowan. 2000. On Christian Theology. Oxford: Blackwell.

Williams, Rowan. 2018. Christ the Heart of Creation. London: Bloomsbury.

Wyschogrod, Edith. 1990. Saints and Postmodernism: Revisioning Moral Philosophy. Chicago and London: University of Chicago Press.

Žižek, Slavoj. 2002. Welcome to the Desert of the Real: Five Essays on September 11 and Related Dates. London and New York: Verso.

Žižek, Slavoj. 2016. Against the Double Blackmail: Refugees, Terror and Other Trouble with Neighbours. Milton Keynes: Allen Lane.

Žižek, Slavoj. 2017. The Courage of Hopelessness: Chronicles of a Year of Acting Dangerously. London: Allen Lane.

Žižek, Slavoj, Eric L. Santner, and Kenneth Reinhard. 2005. The Neighbor: Three Enquiries in Political Theology. Chicago and London: The University of Chicago Press.

(C) 2020 by the author. Licensee MDPI, Basel, Switzerland. This article is an open access article distributed under the terms and conditions of the Creative Commons Attribution (CC BY) license (http://creativecommons.org/licenses/by/4.0/). 